\title{
研究ノート
}

\section{マイクロ波を利用した淡水の水位・電気伝導度 および淡塩水境界位の計測システム}

\author{
伊藤祐二 1）郡山益実 2) 宮本 英揮 2) \\ 梅谷 知弘 3) 筑紫二郎 4)
}

1) 佐賀大学低平地沿岸海域研究センター

（于840-8502 佐賀市本庄町1）

2) 佐賀大学農学部

（干840-8502 佐賀市本庄町1）

3) 太陽計器株式会社

（干114-0032 東京都北区中十条1-12-3）

4) 九州大学生物環境調節センター

（テ812-8581福岡市東区箱崎6-10-1）

本報では，沿岸帯水層における淡水の水位 $h_{\mathrm{fw}}$ と電気伝導度 $(\mathrm{EC}) \sigma_{\mathrm{fw}}$, 淡塩水境界位 $h_{\mathrm{i}}$ の計測システムを開発する ために，それら3者の計測方法を紹介するとともに，同システムの有効性を室内実験によって評価した．各計測には， 対象媒質中におけるマイクロ波の伝播特性を評価できる時間領域反射法（TDR）を利用した. 2つのTDRプローブの うち，一方を $h_{\mathrm{fw}}-\sigma_{\mathrm{fw}}$ 計測，他方を $h_{\mathrm{i}}$ 計測に供し，1台のケーブルテスターからマイクロ波ステップパルスを各プロー ブのロッド部に送り，得られたTDR波形に基づいて $h_{\mathrm{fw}}, \sigma_{\mathrm{fw}}, h_{\mathrm{i}}$ を決定した．地下水観測井戸を模擬した円筒カラム にTDRプローブを垂直に設置し，異なる $\sigma_{\mathrm{fw}}$ 条件において淡水面または淡塩水境界面を創出することで， $h_{\mathrm{fw}}$ まは $h_{\mathrm{i}}$ の上昇過程におけるTDR波形を計測した。その結果， $h_{\mathrm{fw}}$ の上昇過程の波形からロッドの根端－先端間を往復するパ ルスの伝播時間 $t_{\mathrm{t}}$ とプローブ周囲のトータル EC $\left(\sigma_{\mathrm{t}}\right)$ を $h_{\mathrm{i}}$ の上昇過程の波形から淡水中のパルスの往復伝播時間 $t_{\mathrm{fw}}$ を得た。ささらに, $h_{\mathrm{fw}}$ は $t_{\mathrm{t}}$ の， $\sigma_{\mathrm{fw}}$ は $\sigma_{\mathrm{t}}$ の， $h_{\mathrm{i}}$ は $t_{\mathrm{fw}}$ の各1次式に基づいて，それぞれ高精度で計測できることを確認 した． $h_{\mathrm{fw}}$ と $h_{\mathrm{i}}$ の間に挟まれた淡水層厚を淡水領域， $\sigma_{\mathrm{fw}}$ を淡水の塩分濃度の指標とすることにより，提案したシステ ムは沿岸の地下淡水資源の質的および量的評価に有効に活用できるものと推察する.

キーワード：時間領域反射法（TDR）, 沿岸帯水層, 地下水モニタリング, 塩水化, 淡水資源

\section{I 、はじめに}

水源の乏しい島嶼地域や半島部では，沿岸の地下 水は貴重な淡水資源である。ところが, 沿岸带水層 の下部には，一般に海水が楔状に侵入しているため (図一-1), 利水可能な淡水は常に塩水化の危険に曝 されている。こうした状況にある沿岸の地下淡水資 源を保全・管理し，持続的な利用を図るためには， 淡水の塩分濃度を調べ, 淡水領域の経時変化を把握 することが重要である。

淡水の塩分濃度は，それと正の相関を有する電気 伝導度 (Electrical conductivity：EC）から推定する ことができる。淡水領域は, 地下水面と帯水層下部
に形成される淡塩水境界面とに挟まれた淡水層 (図一1）の厚さ（淡水層厚）として定義できる。淡 水の $\mathrm{EC} に$ 加え, 地下水位 (淡水位) と淡塩水境界 位を一体的に計測できれば，淡水の塩分濃度とその

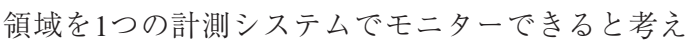
られるが，そのような計測システムは未開発である。 こうした状況を受けて, 近年, 著者らは, 淡水の水 位, EC, 淡塩水境界位の計測システムの構築を目 指し，マイクロ波を利用したそれらの計測法につい て検討してきた（宮本ら，2008；伊藤ら，2009， 2010)。そ己で，本報では，これまで検討してきた 淡水の水位, $\mathrm{EC}$, 淡塩水境界位の計測システムの 


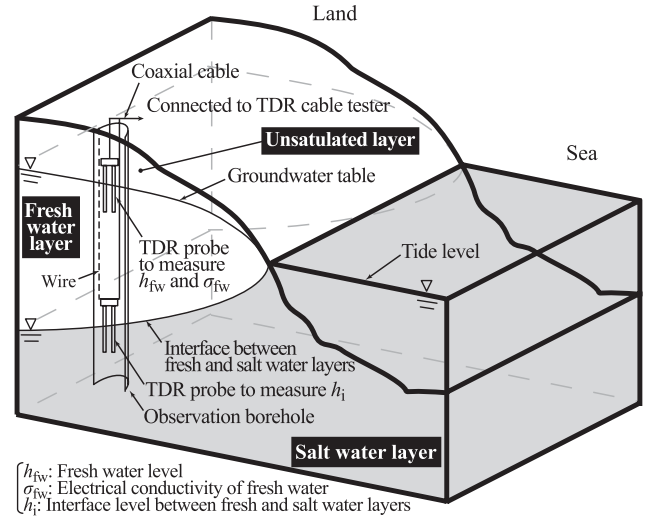

図 -1 淡水の水位と $\mathrm{EC}$, 淡塩水境界位の現地観測の模 式図

Fig. 1 Schematic diagram of field observations for fresh water level, EC of fresh water, and interface level between fresh and salt water layers.

概要と計測方法を紹介するとともに，同システムの 有効性を評価するために実施した地下水観測の模擬 実験の結果について報告する。

\section{II 。計測システム}

淡水の水位と $\mathrm{EC}$, 淡塩水境界位は, 物質中にお けるマイクロ波の伝播特性を評価できる時間領域反 射法（Time domain reflectometry：TDR）に基づいて 計測する。それらの計測システムは, 土壤の水分と 塩分の計測において，従来から使用されてきたTDR 計測システムと同様の機器で構成される $($ 写真一 1$)$. その基本構成は, 広帯域（たとえば，0１.75 GHz） のマイクロ波ステップパルスの送信器とその反射波 形（TDR波形）の計測器を内蔵するTDRケーブルテ スター (Campbell Scientific, TDR100), TDRプロー ブ，TDR波形のデータを記録するためのデータロガー (Campbell Scientific, CR1000), 12 Vバッテリー (Campbell Scientific，PS100）である。計測には，2つ のプローブを用いることとし，一方を淡水の水位と $\mathrm{EC}$ 同時計測, 他方を淡塩水境界位の計測に供する. 本実験では, 長さ $48 \mathrm{~cm}$ (淡水のECが $0.013 \mathrm{~S} \mathrm{~m}^{-1}$ の場 合， $4.2 \mathrm{~m}$ まで延長可能：伊藤ら，2009，2010), 直 径 $0.4 \mathrm{~cm}$ の2本の先鋭なステンレス鋼ロッドを， 1 $\mathrm{cm}$ 間隔で平行に配置した2線式TDRプローブを使用 した。なお，パルスの伝播経路を切り替えるマルチ プレクサー（Campbell Scientific，SDMX50）を用い れば, 1 台のケーブルテスターで複数のプローブ

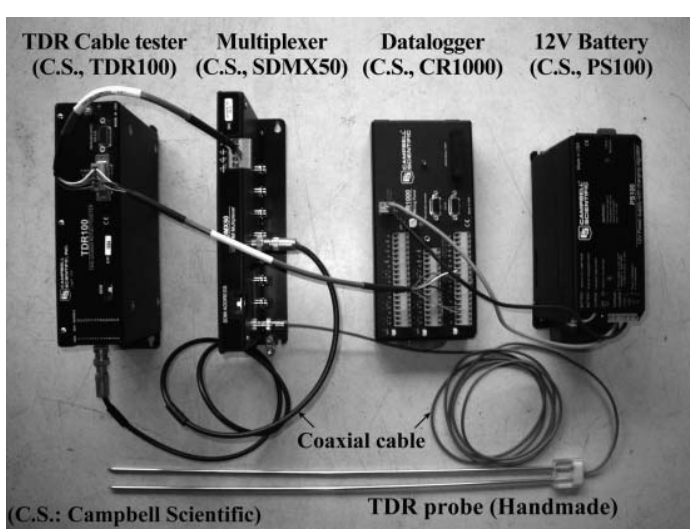

写真 -1 計測システムの基本構成

Photo 1 Fundamental composition of the measurement system.

を制御することができる。

\section{III. 計测法}

\section{1. 淡水の水位とECの同時計測}

淡水位は，プローブのロッド根端一先端間を往復 するパルスの伝播時間 $t_{\mathrm{t}}(\mathrm{s})$ に基づいて求められる (図一2の上側の波形)。淡水面に垂直に静置したプ ローブのロッド部にケーブルテスターからマイクロ 波のステップパルスを発信すると, 得られるTDR波 形には，ロッド先端でパルスが反射したことを示す 反射係数 $\rho$ (無次元) の急増が観察される. $\rho$ の急 増が生じた時間を $t_{1}(\mathrm{~s})$, 空気中と淡水中で別途計 測した波形において両波形が分岐した時間を $t_{0}(\mathrm{~s})$ （図一2の下側の波形）と定め, $t_{\mathrm{t}}=t_{1}-t_{0}$ とすると， プローブ周囲の媒質のトータル比誘電率 $\varepsilon_{\mathrm{t}}$ (無次元) は， $t_{\mathrm{t}}$ の関数として次式で与えられる（Dalton et al., 1984)

$$
\varepsilon_{\mathrm{t}}=\left(\frac{c t_{\mathrm{t}}}{2 L}\right)^{2}
$$

ここで, $c$ は真空に扔ける光速 $\left(3.0 \times 10^{8} \mathrm{~m} \mathrm{~s}^{-1}\right), L$ はロッド長 $(\mathrm{m})$ である。また, 空気の比誘電率を $\varepsilon_{\mathrm{a}}(=1)$, 淡水の比誘電率を $\varepsilon_{\mathrm{fw}}$, ロッド先端から淡 水面までの距離を $h_{\mathrm{fw}}(\mathrm{m})$ とすると， $\varepsilon_{\mathrm{t}}$ の平方根は， $\varepsilon_{\mathrm{a}}$ と $\varepsilon_{\mathrm{fw}}$ の合成值として次式で表される（Robinson et al., 2003 ; 宮本ら，2008）.

$$
\sqrt{\varepsilon_{\mathrm{t}}}=\frac{L-h_{\mathrm{fw}}}{L} \sqrt{\varepsilon_{\mathrm{a}}}+\frac{h_{\mathrm{fw}}}{L} \sqrt{\varepsilon_{\mathrm{fw}}}
$$

上式中の $\varepsilon_{\mathrm{fw}}$ は, ロッド全部を淡水中に没した状 


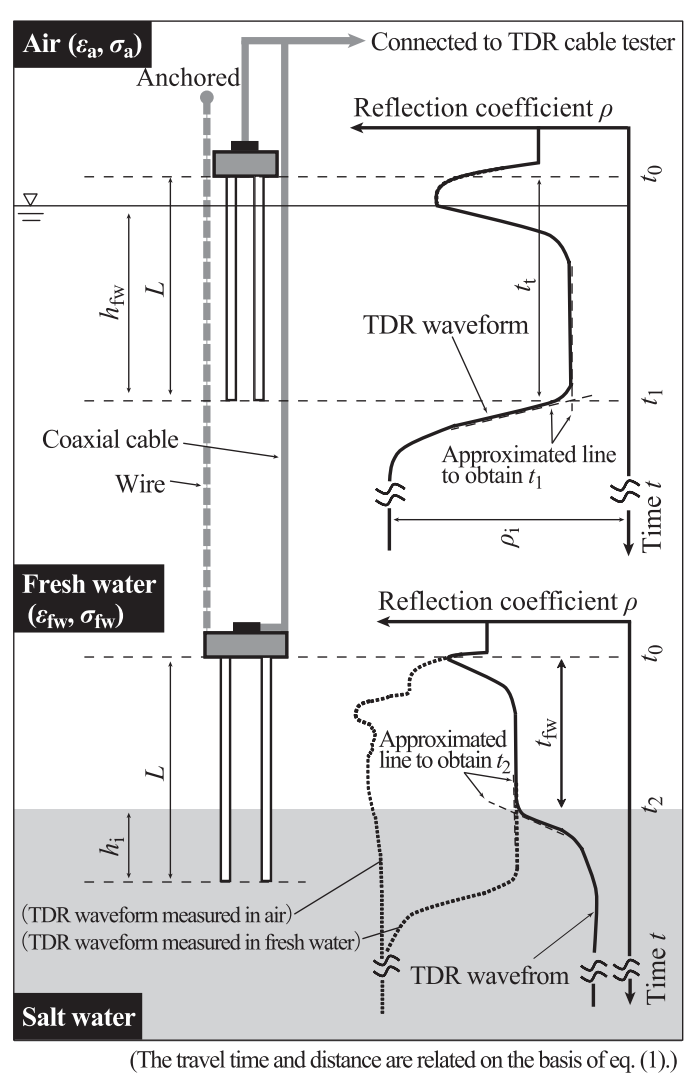

図-2 淡水の水位 $-E C$ 計測と淡塩水境界位計測で得ら れるTDR波形の模式図

Fig. 2 Schematic diagram of TDR waveforms derived by measuring water level and EC of fresh water and interface level between fresh and salt water layers.

態で得た $t_{\mathrm{t}}$ を, 式（1）に代入することによって 求めることができる。本報では, 上述の方法で $\varepsilon_{\mathrm{fw}}(=73.1 \pm 1.0) *$ を決定したが, 淡水の温度 $T_{\mathrm{fw}}\left({ }^{\circ} \mathrm{C}\right)$ が既知の場合，次式（国立天文台，2008）でも推定 することができる。

$$
\begin{aligned}
\varepsilon_{\mathrm{fw}}= & 88.15-0.414 T_{\mathrm{fw}}+0.131 \\
& \times 10^{-2} T_{\mathrm{fw}}{ }^{2}-0.046 \times 10^{-4} T_{\mathrm{fw}}{ }^{3}
\end{aligned}
$$

式（1）を式（2）に代入し， $h_{\mathrm{fw}}$ について整理する と, 次式が得られる.

$$
h_{\mathrm{fw}}=\frac{c t_{\mathrm{t}}-2 L \sqrt{\varepsilon_{\mathrm{a}}}}{2\left(\sqrt{\varepsilon_{\mathrm{fw}}}-\sqrt{\varepsilon_{\mathrm{a}}}\right)}
$$

$t_{0}$ の位置は，計測システム全体の電気的特性が変わ らない限りは不変であるが, $t_{1}$ の位置は, ロッドに 接する空気と淡水の層厚比によって変化する。つま り, 水位が変化し，層厚比が変わると $t_{1}$ が変化し， その $t_{1}$ から求めた $t_{\mathrm{t}}$ 変化することになる。したがっ て，TDR波形から測定した $t_{\mathrm{t}}$ を式（4）に代入するこ とによって， $h_{\mathrm{fw}}$ を決定することができる。なお， 本報では, $\rho$ 值の急变位置前後の波形線に手動で2 本の近似直線を描き, それらの交点に基づいて $t_{1}$ を 決定した（図一2の上側の波形）.

一方, 淡水のECは, 計測した $h_{\mathrm{fw}}$ と, $h_{\mathrm{fw}}$ 計測で得 たTDR波形の末端の反射係数 $\rho_{\mathrm{i}}$ (図一2の上側の波 形末端）に基づいて決定される。ケーブルテスター から発信されたパルスが同軸ケーブルを通ってプロー ブのロッド先端で反射して戻る過程では，パルスの 電気エネルギーの一部が失われ，その損失の程度が $\rho_{\mathrm{i}}$ 值に反映される。空気中で測定した $\rho_{\mathrm{i}}$ を $\rho_{\mathrm{i}}$, air 空気中でプローブを短絡させて測定した $\rho_{\mathrm{i}}$ を $\rho_{\mathrm{i} \text {, short }}$ とすると, 計測した $\rho_{\mathrm{i}}$ からケーブルに扔けるパルス のエネルギー損失の影響を補正した $\rho_{\mathrm{i}, \mathrm{c}}$ は, 次式で 与えられる (Castiglione and Shouse, 2003).

$$
\rho_{\mathrm{i}, \mathrm{c}}=\frac{2\left(\rho_{\mathrm{i}}-\rho_{\mathrm{i}, \text { air }}\right)}{\rho_{\mathrm{i}, \text { air }}-\rho_{\mathrm{i}, \text { short }}}+1
$$

$\rho_{\mathrm{i}, \mathrm{c}}$ に基づき, プローブ周囲のトータルEC $\left(\sigma_{\mathrm{t}}\right)\left(\mathrm{S} \mathrm{m}^{-1}\right)$ は次式で求められる (Topp et al., 1988 ; Castiglione and Shouse, 2003).

$$
\sigma_{\mathrm{t}}=\frac{K_{\mathrm{p}}}{Z}\left(\frac{1-\rho_{\mathrm{i}, \mathrm{c}}}{1+\rho_{\mathrm{i}, \mathrm{c}}}\right)
$$

ここで, $K_{\mathrm{p}}$ はプローブ定数 $\left(\mathrm{m}^{-1}\right), Z$ はケーブルの インピーダンス $(\Omega)($ 一般に $Z=50 \Omega)$ である. また, 本研究では, 空気と淡水のECを $\sigma_{\mathrm{a}}$ と $\sigma_{\mathrm{fw}}$ とし, $\sigma_{\mathrm{t}}$ が両者の合成値として次式で表されるものとする.

$$
\sigma_{\mathrm{t}}=\frac{L-h_{\mathrm{fw}}}{L} \sigma_{\mathrm{a}}+\frac{h_{\mathrm{fw}}}{L} \sigma_{\mathrm{fw}}
$$

上式中の $\sigma_{\mathrm{a}}$ を0とみなすと， $\sigma_{\mathrm{fw}}$ は次式で与えられる.

$$
\sigma_{\mathrm{fw}}=\frac{L}{h_{\mathrm{fw}}} \sigma_{\mathrm{t}}
$$

淡水の水位とECの同時計測では, 式 (4) で求めた

\footnotetext{
*実験用カラムの壁面が $\varepsilon_{\mathrm{fw}}$ 計測に影響したため, 本報で得られた $\varepsilon_{\mathrm{fw}}$ は実験時の $T_{\mathrm{fw}}=24.8^{\circ} \mathrm{C}$ に対する $\varepsilon_{\mathrm{fw}}=78.6$ を過小評価したが, このことが境界面位置の計測に影響を及ぼさないことは, 既往の研究（たとえば，伊藤ら，2009）で確認されている.
} 
$h_{\mathrm{fw}}$ と式（6）で求めた $\sigma_{\mathrm{t}}$ を式（8）に代入することに よって $\sigma_{\mathrm{fw}}$ が測定される。なお，本報では， $K_{\mathrm{p}}$ を $\mathrm{EC}$ が既知の蒸留水中 $\left(=0.0001 \mathrm{~S} \mathrm{~m}^{-1}\right)$ と水道水中 $(=$ $0.045 \mathrm{~S} \mathrm{~m}^{-1}$ ) で測定した $\rho_{\mathrm{i}}$ に基づいて校正した。

\section{2. 淡塩水境界位の計測}

淡塩水境界位は，淡水中を往復するパルスの伝播 時間 $t_{\mathrm{fw}}(\mathrm{s})$ に基づいて決定される（図一2の下側の 波形)。水中に垂直に没したプローブのロッド根 端一先端間に淡塩水境界面が存在するとき，ケーブ ルテスターから与えたパルスがロッドを伝播する過 程では，パルスの電気エネルギーが高導電性の塩水 に吸収されたことを示す， $\rho$ の急減が波形上に現れ る。計測波形において, $\rho$ の急減が生じた時間を $t_{2}$ (s) とすると, $t_{\mathrm{fw}}$ は $t_{2}$ と $t_{0}$ の差 $\left(=t_{2}-t_{0}\right)$ として計 算される。ロッド先端から境界面までの距離を $h_{\mathrm{i}}$ （m）とし，ロッドと接する淡水の厚さを $L-h_{\mathrm{i}}$ とす ると， $\varepsilon_{\mathrm{fw}}, t_{\mathrm{fw}}, L-h_{\mathrm{i}}$ に式（1）の関係を適用する ことによって， $h_{\mathrm{i}}$ は次式で与えられる（伊藤ら， 2010).

$$
h_{\mathrm{i}}=L-\frac{c t_{\mathrm{fw}}}{2 \sqrt{\varepsilon_{\mathrm{fw}}}}
$$

なお， $t_{2}$ は $t_{1}$ の決定法と同様に, $\rho$ 值の急減位置前 後における2本の波形近似直線の交点に基づいて決 定した（図一2の下側の波形）。

\section{IV．結果と考察}

水位一EC計測実験では，観測井戸を模擬した内

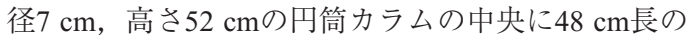
プローブを垂直に設置し, カラム内に淡水を給水す ることで水位 $h_{\mathrm{fw}}$ の上昇過程を創出し, 異なる $h_{\mathrm{fw}}$ に おけるTDR波形を計測した。その結果，得られた波 形上の $\rho$ 值の急変位置 $\left(t_{1}\right.$ の位置) は, $h_{\mathrm{fw}}$ の上昇に 応じて増大した $($ 図一 3$)$.この $t_{1}$ の上昇傾向は, 他 の $\sigma_{\mathrm{fw}}$ 条件でも同様に認められた。ただし， $\sigma_{\mathrm{fw}}$ が大 きい場合には（図一3 (b)), パルスが淡水中を伝播 する過程で減衰するため, $h_{\mathrm{fw}}=0 \mathrm{~m}$ を除く波形の $t_{1}$ 付近の $\rho$ 值は， $\sigma_{\mathrm{fw}}$ が低い場合（図一3 (a)) に比べ て小さかった。 $\sigma_{\mathrm{fw}}$ 条件によって，そうした違いは 認められたものの, 同一の $h_{\mathrm{fw}}$ 条件に対する $t_{1}$ は, 概 ね一定であった。 $h_{\mathrm{fw}}$ の実測值に対するTDR計測值 の平均二乗誤差の平方根 (Root mean square error : RMSE）を計算した結果， $\sigma_{\mathrm{fw}}=0.004 ， 0.01 ， 0.05$, (a) $\sigma_{\mathrm{fw}}=0.004 \mathrm{~S} \mathrm{~m}^{-1}$

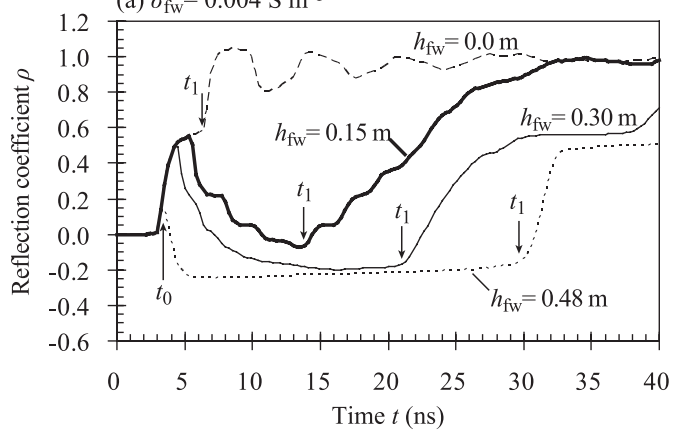

(b) $\sigma_{\mathrm{fw}}=0.1 \mathrm{~S} \mathrm{~m}^{-1}$

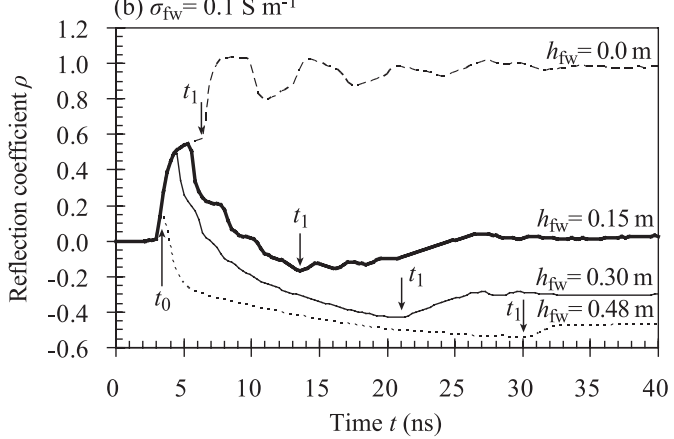

図-3 淡水の水位-EC計測実験で得られたTDR波形 $\left(h_{\mathrm{fw}}=0.0,0.15,0.30,0.48 \mathrm{~m}\right.$ の場合を例示. $t_{0}$ はロッド根端， $t_{1}$ は淡水面におけるパルスの反 射を表す.)

Fig. 3 TDR waveforms derived in the experimental measurements of water level and EC of fresh water. (Cases of $h_{\mathrm{fw}}=0.0,0.15,0.30,0.48 \mathrm{~m}$ are illustrated. $t_{0}$ and $t_{1}$ represent pulse reflections at the root of rod and the surface of fresh water, respectively.)

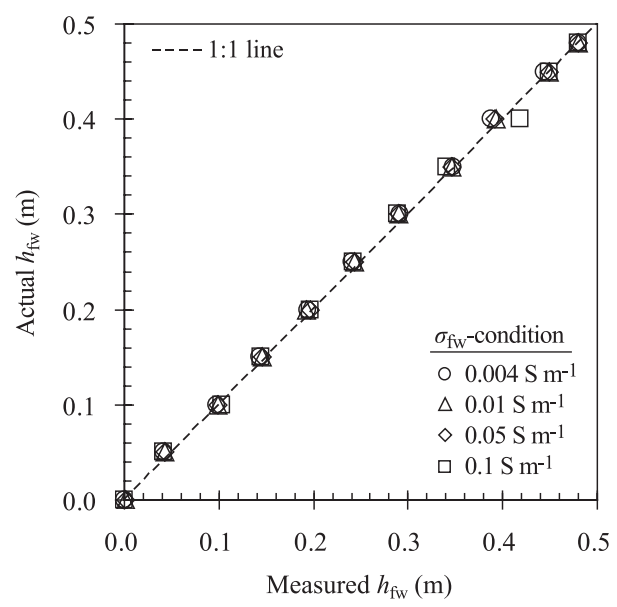

図-4 淡水位 $h_{\mathrm{fw}}$ の実測值と式（4）を介したTDR計測 值との比較

Fig. 4 Comparison of actual $h_{\mathrm{fw}}$ and measured $h_{\mathrm{fw}}$ by TDR (eq. (4)) 
$0.1 \mathrm{~S} \mathrm{~m}^{-1}$ におけるRMSEはそれぞれ0.7，0.6，0.5， $0.8 \mathrm{~cm}$ となり, 式 (4) に基づいて $h_{\mathrm{fw}}$ を精度よく測 定できることが明らかとなった（図一4）.

また，上述の $4 つ の \sigma_{\mathrm{fw}}$ 条件では， $\sigma_{\mathrm{t}}$ が水位上昇に 応じて直線的に増大する結果が得られた（図一5）。 ただし， $h_{\mathrm{fw}}=0.05 \sim 0.25 \mathrm{~m}$ では， $\sigma_{\mathrm{t}}$ を測定できない 場合が生じた。これは，この範囲の $h_{\mathrm{fw}}$ では計測し たTDR波形の $\rho$ 值が小刻みに変動したため（図一3 の $h_{\mathrm{fw}}=0.15 \mathrm{~m}$ の波形), 波形の自動解析ソフト (Or et al., 2004）で $\rho_{\mathrm{i}}$ の解析機能が起動しなかったこと が原因である。計測した $\sigma_{\mathrm{t}}$ と $h_{\mathrm{fw}}$ を式（8）に代入し， 同式から得た $\sigma_{\mathrm{fw}}$ を実測值と比較したところ，4つの

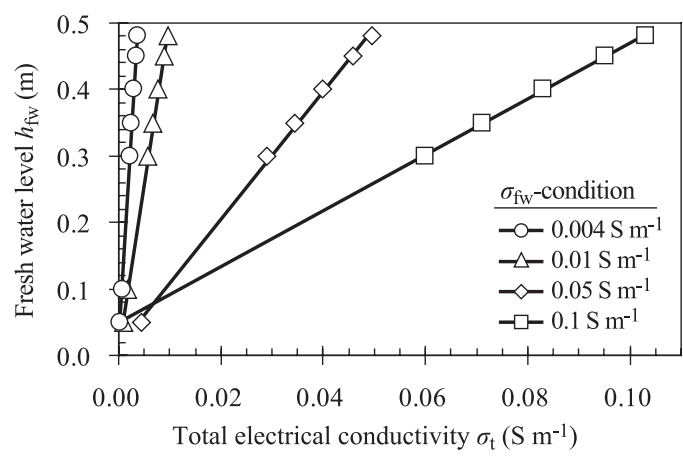

図-5 淡水の水位 $-\mathrm{EC}$ 計測実験で得られた水位 $h_{\mathrm{fw}}$ と トータルEC $\left(\sigma_{\mathrm{t}}\right)$ との関係

Fig. 5 Relationship between water level $h_{\mathrm{fw}}$ and total EC $\left(\sigma_{\mathrm{t}}\right)$ obtained in the experimental measurements of water level and EC of fresh water.

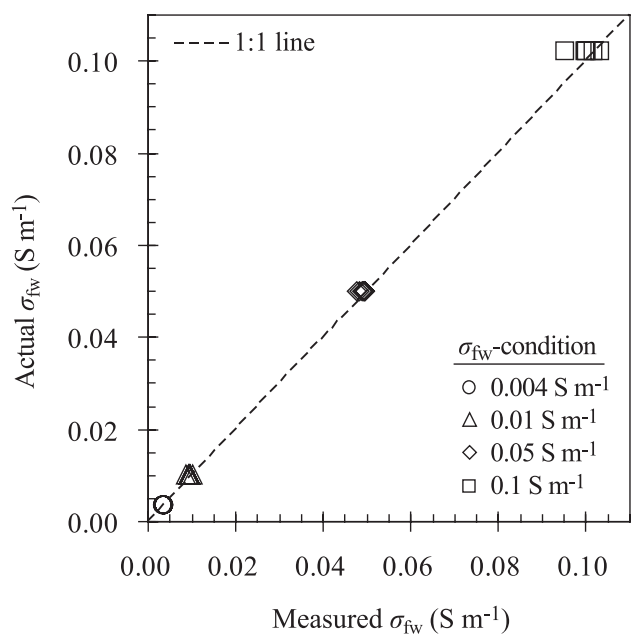

図一6 淡水のEC（ $\left.\sigma_{\mathrm{fw}}\right)$ の実測值と式（8）を介した TDR計測值との比較

Fig. 6 Comparison of actual $\sigma_{\mathrm{fw}}$ and measured $\sigma_{\mathrm{fw}}$ by TDR (eq. (8)).
的条件におけるRMSEはそれぞれ0.0001，0.0008， 0.001，0.003 $\mathrm{S} \mathrm{m}^{-1}$ となった (図一6). よって， $\sigma_{\mathrm{t}}$ が 決定できれば，それと式（4）で評価した $h_{\mathrm{fw}}$ を式 （8）に代入することにより，同式から $\sigma_{\mathrm{fw}}$ を精度よ く推定できることが明らかになった。

一方, 淡塩水境界位の計測実験では, 淡水で満た したカラムの中央に $48 \mathrm{~cm}$ 長プローブを挿入して固 定し，底部からゆっくりと塩水を給水して境界位 $h_{\mathrm{i}}$ の上昇過程を創出し, 異なる $h_{\mathrm{i}}$ におけるTDR波形を 計測した。その結果，計測した波形上のパルスのエ ネルギー急減位置 $\left(t_{2}\right.$ の位置) は, $h_{\mathrm{i}}$ の上昇に応じ て低下した (図一7). 同様の傾向は, 他の $\sigma_{\mathrm{fw}}$ 条件 でも認められた。低 $\sigma_{\mathrm{fw}}$ 条件（図一7（a)）に比べ, 高 $\sigma_{\mathrm{fw}}$ 条件（図一7 (b)) では, $t_{2}$ 付近の $\rho$ 值が低下 したものの, 同一の $h_{\mathrm{i}}$ 条件に対する $t_{2}$ は概ね一致し

(a) $\sigma_{\mathrm{fw}}=0.004 \mathrm{~S} \mathrm{~m}^{-1}$

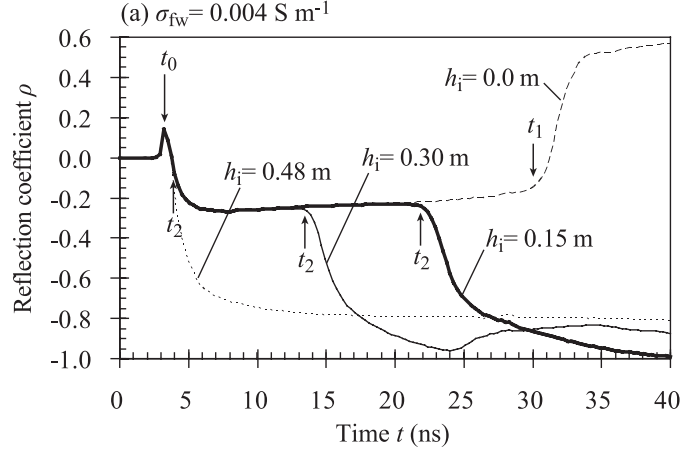

(b) $\sigma_{\mathrm{fw}}=0.1 \mathrm{~S} \mathrm{~m}^{-1}$

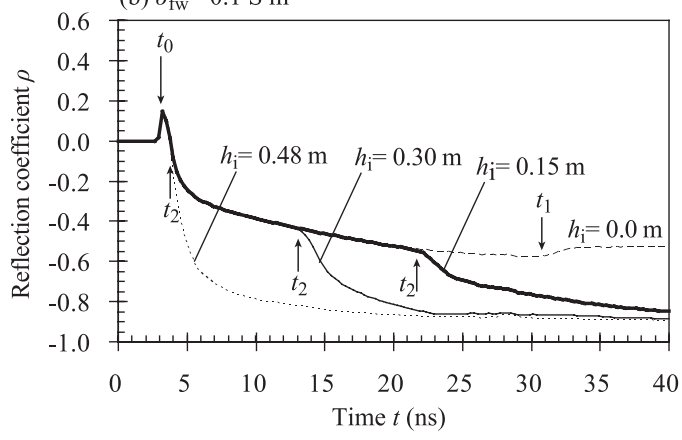

図-7 淡塩水境界位の計測実験で得られたTDR波形 $\left(h_{\mathrm{fw}}=0.0,0.15,0.30,0.48 \mathrm{~m}\right.$ の場合を例示. $t_{0}$ はロッド根端におけるパルスの反射， $t_{2}$ は淡塩 水境界面におけるパルスの吸収を表す.)

Fig. 7 TDR waveforms derived in the experimental measurements of interface level between fresh and salt water layers. (Cases of $h_{\mathrm{fw}}=0.0,0.15,0.30,0.48 \mathrm{~m}$ are illustrated. $t_{0}$ represents pulse reflection at the root of rod and $t_{1}$ represents pulse absorption at the interface between fresh and salt water layers.) 


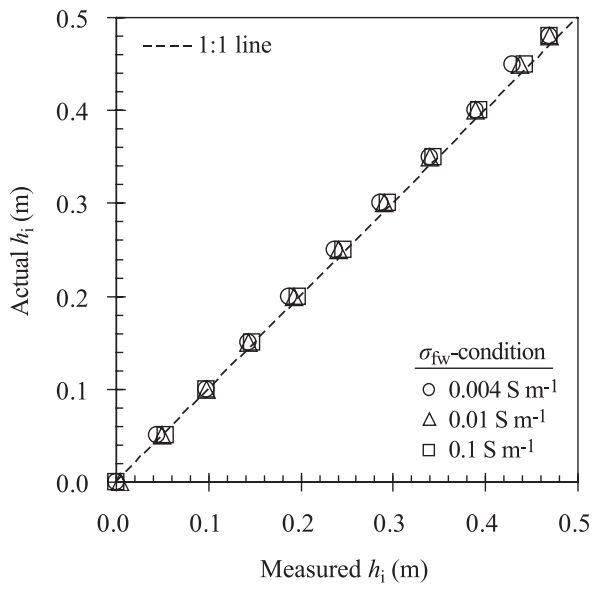

図 - 8 淡塩水境界位 $h_{\mathrm{i}}$ の実測值と式（9）を介したTDR 計測值との比較

Fig. 8 Comparison of actual $h_{\mathrm{i}}$ and measured $h_{\mathrm{i}}$ by TDR (eq. (9)).

た. $t_{2}$ に基づいて決定した $t_{\mathrm{fw}}$ を式 (9)に代入し，同式 から得た $h_{\mathrm{i}}$ を実測值と比較したところ， $\sigma_{\mathrm{fw}}=0.004$ ， 0.01，0.1 S m $\mathrm{S}^{-1}$ におけるRMSEはそれぞれ0.8，0.4， $0.5 \mathrm{~cm}$ とった (図一8).これらの結果から， $h_{\mathrm{i}}$ は 式（9）に基づいて高精度で計測できることが判明 した。

\section{V。おわりに}

本報では, 淡水の水位, $\mathrm{EC}$, 淡塩水境界位の計 測システムと各々の計測法について概説し，それら の有効性を評価した室内実験の結果について報告し た。実験では，土壤科学分野で多用されるTDRの計 測システムをほぼそのまま利用したため, 水位一 $\mathrm{EC}$ 計測または淡塩水境界位計測で得られた複雑な 凹凸状のTDR波形を自動解析できず，手動で解析せ ざるを得なかった。 そのため, 野外で長期間使用で きる計測システムとするために, 今後, 波形取得か ら各測定值を得るまでの計測全般を自動化すること が重要である。また，長期観測に耐え得る頑健なプ
ローブやケーブルを使用するなど，計測システムの ハード面の改良も望まれる。しかしながら, 室内実 験では，現システムに大きな改良を加えなくても淡 水位, $\mathrm{EC}$, 淡塩水境界位を高精度で評価できるこ とが確認され, 紹介した計測技術は沿岸地下の淡水 資源のモニタリングに有用であると考える.今後は， 本システムの関連機器の開発や販売を専門とする民 間企業の協力を得て, システムの実用化に向けた研 究・開発に取り組む予定である。

\section{引用文献}

Castiglione P, Shouse PJ. 2003. The effect of ohmic cable losses on time-domain reflectometry measurements of electrical conductivity. Soil Science Society of America Journal 67: 414-424. DOI: 10.2136/sssaj2003.4140.

Dalton FN, Herkelrath WN, Rawlins DS, Rhoades JD. 1984. Time-domain reflectometry measurement of soil water content and electrical conductivity with a single probe. Science 224: 989-990. DOI: 10.1126/science.224.4652.

伊藤祐二・宮本英揮・筑紫二郎 2009. 時間領域反射法による 水中の堆積土砂表面位および電気伝導度の同時計測. 農業農 村工学会論文集 $263: 81-90$.

伊藤祐二・宮本英揮・郡山益実・筑紫二郎・瀬口昌洋 2010 . マイクロ波のエネルギー吸収特性を利用した淡塩水境界面の 計測. 土木学会論文集B $66: 189-195$.

国立天文台編 2008. 理科年表. 丸善； 412 .

宮本英揮・筑紫二郎 - 吳 宅根 2008. 時間領域反射法による水 位・電気伝導度および土砂表面位の計測. 土壤の物理性 $108: 37-45$.

Or D, Jones SB, VanShaar JR, Humphries S, Koberstein L. 2004. WinTDR - Users Guide-for Ver. 6.1, Department of Plants, Soil and Biometeorology, Utah State University, Logan Utah, USA. http://soilphysics.usu.edu/wintdr/ index.htm. (参照 : 2010/04/14).

Robinson DA, Schaap M, Jones SB, Friedman SP, Gardner CMK. 2003. Considerations for improving the accuracy of permittivity measurement using time domain reflectometry: air-water calibration, effects of cable length. Soil Science Society of America Journal 67: 62-70. DOI: 10.2136/ sssaj2003.6200.

Topp GC, Yanuka M, Zebchuk WD, Zegelin S. 1988. Determination of electrical conductivity using time domain reflectometry: Soil and water experiments in coaxial lines. Water Resources Research 24: 945-952. DOI: 10.1029/ WR024i007p00945.

(受付：2010年10月13日，受理：2011年2月4日) 


\title{
Microwave Measurement System of Fresh Water Level, Electrical Conductivity of Fresh Water, and Interface Level between Fresh and Salt Water Layers
}

\author{
Yuji ITO 1) Masumi KORIYAMA ${ }^{2)}$ Hideki MIYAMOTO ${ }^{2)}$ \\ Tomohiro UMETANI $^{3)}$ Jiro CHIKUSHI ${ }^{4)}$ \\ 1) Institute of Lowland and Marine Research, Saga University \\ (1 Honjo-machi, Saga 840-8502, Japan) \\ 2) Faculty of Agriculture, Saga University \\ (1 Honjo-machi, Saga 840-8502, Japan) \\ 3) Taiyo Keiki Inc. \\ (1-12-3 Nakajujo, Kita-ku, Tokyo 114-0032, Japan) \\ 4) Biotron Institute, Kyushu University \\ (6-10-1 Hakozaki, Higashi-ku, Fukuoka 812-8581, Japan)
}

\begin{abstract}
To develop a measurement system of the fresh water level $h_{\mathrm{fw}}$, the electrical conductivity (EC) of fresh water $\sigma_{\mathrm{fw}}$, and the fresh-water/salt-water interface level $h_{\mathrm{i}}$ in a coastal aquifer, the measurement methods were presented and the measurement system was examined through laboratory experiments. In the system, time domain reflectometry (TDR) that can evaluate the propagation-characteristics of a microwave step-pulse traveling through a material was employed. The $h_{\mathrm{fw}}$ and $\sigma_{\mathrm{fw}}$ were simultaneously evaluated based on the TDR waveform measured with a single TDR probe, while $h_{\mathrm{i}}$ was evaluated based on the TDR waveform measured with another probe. For the rising processes of $h_{\mathrm{fw}}$ or $h_{\mathrm{i}}$ under different $\sigma_{\mathrm{fw}}{ }^{-}$ conditions, TDR waveforms responding to the step-pulse given to the probe from the cable tester were measured with the probes set vertically in an experimental column as a hypothetical borehole. From the waveforms measured during $h_{\mathrm{fw}}$-rising, we could derive the travel times $t_{\mathrm{t}}$ of the pulses going and returning through the transmission line between the root and tip of the probe and do the total $\mathrm{EC}\left(\sigma_{\mathrm{t}}\right)$ around the probe. The travel times $t_{\text {fw }}$ of the pulses going and returning through the line in the fresh water layer could also be derived from the waveforms measured during $h_{\mathrm{i}}$-rising. Comparisons of actual and TDR measurements of $h_{\mathrm{fw}}, \sigma_{\mathrm{fw}}$, and $h_{\mathrm{i}}$ showed that they could be reasonably estimated with respective linear functions of $t_{\mathrm{t}}, \sigma_{\mathrm{t}}$, and $t_{\mathrm{fw}}$. Understanding the amount of fresh water based on the water layer thickness between measured $h_{\mathrm{fw}}$ and $h_{\mathrm{i}}$ as well as understanding the saline concentration of fresh water by measured $\sigma_{\mathrm{fw}}$, we believe that the present system is effective for monitoring the quality and quantity of fresh water resources in a coastal aquifer.
\end{abstract}

Key words : time domain reflectometry (TDR), coastal aquifer, groundwater monitoring, salinization, fresh water resources 